University of Nebraska - Lincoln

DigitalCommons@University of Nebraska - Lincoln

Agronomy \& Horticulture -- Faculty Publications

Agronomy and Horticulture Department

$12-1919$

\title{
Relative Transpiration of Coniferous and Broad-Leaved Trees in Autumn and Winter
}

J. E. Weaver

University of Nebraska-Lincoln

A. Mogensen

Follow this and additional works at: https://digitalcommons.unl.edu/agronomyfacpub

Part of the Plant Sciences Commons

Weaver, J. E. and Mogensen, A., "Relative Transpiration of Coniferous and Broad-Leaved Trees in Autumn and Winter" (1919). Agronomy \& Horticulture -- Faculty Publications. 432.

https://digitalcommons.unl.edu/agronomyfacpub/432

This Article is brought to you for free and open access by the Agronomy and Horticulture Department at DigitalCommons@University of Nebraska - Lincoln. It has been accepted for inclusion in Agronomy \& Horticulture -Faculty Publications by an authorized administrator of DigitalCommons@University of Nebraska - Lincoln. 


\section{T H E}

\section{Botanical Gazette}

\section{DECEMBER IOI9}

\section{RELATIVE TRANSPIRATION OF CONIFEROUS AND BROAD-LEAVED TREES IN AUTUMN AND WINTER ${ }^{\mathbf{1}}$}

J. E. WEAVER AND A. MOGENSEN

(WITH EIGHTEEN FIGURES)

\section{Introduction}

Transpiration has been of special interest to many investigators for a long time. At first it was considered without reference to environmental factors, but later, as more observations were made and these factors were noted to have a marked effect upon the water loss, they were taken into consideration. Many of the data assembled have been limited to plants during the growing season, so that it has seemed profitable to obtain not only quantitative data on winter losses, but also a comparison of the relative transpiration of conifers and broad-leaved trees in summer and winter.

Various methods have been devised for determining transpiration, from the cut shoot potometer, which usually gives losses quite too low when compared with rooted plants $(6, \mathrm{r} 6)$, to the cobalt chloride method of StaHL (I7), recently improved by Livingston and Shreve (13). With few notable exceptions, such as the method used by ILJIN (II), who worked on xerophytes and mesophytes in the field, the former method has been used largely for laboratory measurements, while the latter, although especially devised for field use, does not take into account the environmental

${ }^{\prime}$ Contribution from the Department of Botany, University of Nebraska, new series, no. 29. 
factors of the habitat under which the plants are growing except as measured by the internal transpiring power of the plant, nor does it give a record of the continuous transpiration losses.

Unquestionably the most reliable data have been those obtained by the potometer, where the entire sealed container was weighed with the whole plant intact. A survey of the literature, however, reveals rather scant data on the transpiring power of trees, especially coniferous trees, regardless of the method employed.

That evergreen trees are constantly supplied with water, even in winter, was first observed by Hales (8), and later by DuHAmel (4), Treviranus (18), and others.

In I860 HARTIG (ro) made some investigations on transpiration losses with Picea, a meter high, in milder winter, and found that the plant lost from about 100-I25 gm. of water a day. These figures, however, are of little value so far as calculating the intensity of transpiration is concerned, since he gave neither area nor weight of the transpiring part.

BURGERSTEIN (3) in 1875 indicated the relation of transpiration to lower temperatures, and showed that cut branches of Taxus baccata transpired in an hour, at $-2^{\circ} \mathrm{C}$., 0.288 per cent, and at - I0. $7^{\circ} \mathrm{C}$., 0.019 per cent of their fresh weight.

That transpiration may take place quite rapidly at rather low temperatures has been shown by WIESNER and PACHER (22). Twigs of Aesculus and Quercus, for example, lost 0.32 and 0.25 per cent respectively of their weight in 24 hours at $-3.5^{\circ}$ to $-10.5^{\circ} \mathrm{C}$., and 0.199 and 0.192 per cent at $-5.5^{\circ} \mathrm{C}$. to $-13.0^{\circ} \mathrm{C}$.

BEACH and Allen (I) found a loss of from 4 to 9 per cent of water in apple twigs during a single week in January, with a minimum temperature of $-26.0^{\circ} \mathrm{C}$. They found also in general that the hardiest varieties were the most resistant to water loss.

According to WARMING (20, p. 3I0), coniferous trees exhale much less water vapor than dicotyledonous trees, due to their xerophytic nature.

KusANo (I2) has given convincing quantitative data on the transpiration of evergreen trees indigenous to Japan. He found that evergreen trees transpired in winter an average quantity of at least $0.48 \mathrm{gm}$. per sq. dm. per day (with the exception of conifers), 
or $16.5^{8} \mathrm{gm}$. per $100 \mathrm{gm}$. of fresh weight in foliage trees, and $8.18 \mathrm{gm}$. in conifers. He also noted that the time of minimum transpiration agrees with that of the minimum temperature, which occurred at the end of January. He states further that the difference in the amount of transpiration of different species of evergreen trees becomes smallest at the time of minimum transpiration; and a change in the external conditions, especially in temperature, does not necessarily produce a corresponding change in transpiration in different species. In average cases the amount of water transpired by foliage evergreen trees is one and a half or two times greater than that transpired by conifers if we reduce the amount either to the fresh weight or to the dry weight of the transpiring part.

VoN HöHNel (I9) estimated that a birch tree, with about 200,000 leaves and standing perfectly free, would evaporate 400 liters of water on a hot dry day. He also has calculated that during the period of vegetation the beech requires 75 liters, and the pine only 7 liters for every $100 \mathrm{gm}$. of leaf substance. The same writer gives us the following table on the relative amount of water transpired from June I to November 30 per Ioo gm. dry weight of leaf:

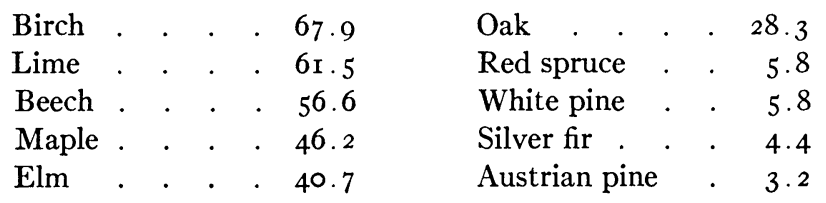

Experiments on the transpiration of seedlings of Acer saccharinum in prairie and shrub thicket have been carried out by WEAVER and ThIEL (2I). Trees placed in the latter habitat lost only 30 per cent as much water per sq. dm. as those in the prairie. Similar experiments with Quercus macrocarpa gave comparable results. The high transpiration losses in the prairie help to explain the absence of trees from such localities.

BERGEN (2) compared the transpiration rates of a number of broad-leaved evergreens, including Olea europaea, Quercus Ilex, and Pistacia Lentiscus, with those of equal leaf surfaces of Ulmus campestris and Pisum satioum. He found that the losses in the 
[DECEMBER

former group were only about 25 per cent less than in the latter, and concluded "that xerophytic leaf structure is not always incompatible with abundant transpiration, but sometimes exists only for use in emergencies to protect the plant from injurious loss of water."

Hanson (9) has shown that the major water losses from the crowns of isolated trees of Ulmus americana, Acer saccharinum, and Fraxinus lanceolata occur from the peripheral branches, and less than one-sixth from equal areas of leaf surface on shaded branches.

The present investigation was undertaken with a double purpose of obtaining data on the relative losses in summer and winter of conifers and broad-leaves, and also to make a beginning on the problem of winter killing of trees and shrubs. This latter project is not included in this paper.

\section{Methods}

In the spring of r918 seedling conifers of Pinus ponderosa Dougl. and Pinus Banksiana Lamb. were obtained from the forest nursery at Halsey, Nebraska; while those of Abies grandis Lindl., Pinus Murrayana Balf., Picea Engelmanni (Parry) Engelm., and Pseudotsuga mucronata (Raf.) Sudw. were secured from the national forests of northern Idaho. These seedlings, varying from two to four years in age, were potted during May in 5-, 7-, and 8-inch pots respectively, according to the size of the plants and the demands of the root systems, and in soil consisting of two parts of rich garden loam and one part of sand, thoroughly mixed and screened through a one-fourth-inch-mesh sieve. The pots were placed on the lawn near the greenhouse until needed in late summer, and were thoroughly watered every day and sometimes twice a day during the driest periods. A few trees, mostly white fir and Engelmann spruce, died. These, with numerous weaker individuals of other species, were discarded, and only the very best plants, which showed the most flourishing condition of growth, were used in the experiments; in fact, only about half of the original stock was thus selected and used.

Galvanized iron containers with flat bottoms and straight walls were used in the transpiration work, the size varying according to 
the demands of the root system. Thus, while the 2-year-old Engelmann spruce required containers only 6.5 inches deep by 3.5 inches wide (these were the smallest used), the 3 -year-old yellow pines were grown during the experiments in containers $5 \cdot 5$ inches in diameter and 14 inches deep. Such containers are very desirable, since they combine lightness with appropriate shape for using the minimum amount of soil.

In September, when the trees were transplanted from the pots to the galvanized iron containers, they were handled in such a way as to scarcely disturb the root systems. A layer of coarse gravel 0.25 inches deep was placed in the bottom of each container, to the side of which, extending from the bottom to the top, a heavy glass tube $5 \mathrm{~mm}$. in diameter was fastened with sealing wax. The soil in the flower pots, having been well watered 24 hours previous to transplanting, and the water allowed to drain through the bottom of the pot, was of such a texture that the whole contents could easily be removed by inverting the pot and jarring the edge while holding the soil surface intact with a piece of cloth. This core of soil, containing the root system practically undisturbed, was placed in the new container. In some cases it was necessary to trim away a part of the top of the conical core, but the part removed was always free from roots. Previously the sheet metal container had been filled to such a depth with soil of the same composition as that of the core, that the plant, when put in place, would be at a proper height in relation to the top of the pot. Soil samples for moisture content determinations were taken at this time. Any spaces in the new containers were carefully filled with soil which was properly compacted. Several plants had their root systems more or less disturbed in repotting, and these were discarded. Finally, the pots were sealed.

The seals consisted of petrolatum mixed with paraffin; the latter had a melting point of about $50^{\circ} \mathrm{C}$. Various mixtures were used, from 80 per cent paraffin and 20 per cent petrolatum (by weight) at the beginning of the experiment, when the weather was hot, to 25 per cent paraffin and 75 per cent petrolatum in midwinter. A very satisfactory seal for winter weather consists of the latter mixture poured on the surface of the soil while very hot, and then 
covered with a less plastic seal of about equal parts of the two ingredients. Little difficulty was experienced in keeping a perfect seal intact.

The broad-leaved trees, Acer saccharinum L., Ulmus americana L., and Quercus macrocarpa Michx., were handled in identically the same manner as the preceding, except that they were grown from seed sowed in flats in the greenhouse, but the plants were transferred to pots out of doors in June.

In order to insure uniform soil temperature conditions for all plants concerned, and changes of temperature similar to those under

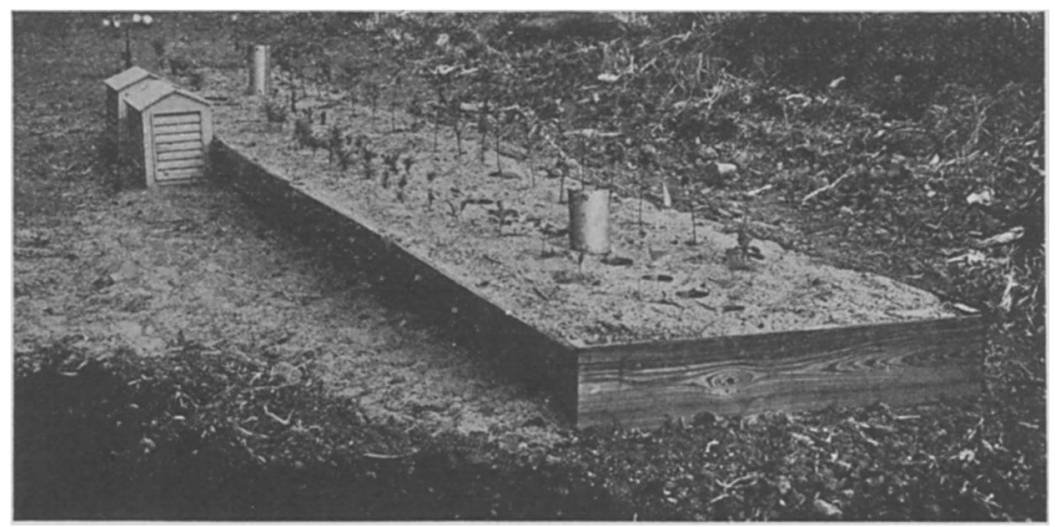

FIG. I.-Arrangement of trees in containers, with collars to insure temperature changes comparable with those of plants growing under natural conditions.

natural conditions, the containers (approximately roo in number) were placed in tin cylindrical collars, each collar being slightly larger than its respective container. These were in rows about 6-ro inches apart and completely surrounded by soil. The top of each container and collar was covered with a heavy woolen blanket, slit to accommodate the stem, and this in turn with a piece of thick muslin waterproofed by infiltration with the hot wax seal mixture. The edges especially, and also the whole cloth, as well as the surrounding soil, were covered with a thin layer of sand. To prevent the drifting of snow among the trees thus planted on the University campus, the collars and inclosed containers were set on the bare soil surface, and the well-tamped soil filled in between them was held in place by a board frame 12 inches high (fig. I.) 
Continuous records of the humidity of the air and the temperature of both air and soil were obtained by means of Friez's hygrothermographs. The last was for a soil depth of 6 inches among the containers. A thermometer placed at a similar depth in one of the medium sized containers, and protected from external atmospheric conditions by means of a felt-lined brass case fitted with a cap, gave readings very similar to those of the soil, as may be seen in table I.

TABLE I

SOIL TEMPERATURE AT A DEPTH OF 6 INCHES INSIDE A CONTAINER, AND AT A SIMILAR DEPTH OUTSIDE IN THE SOIL

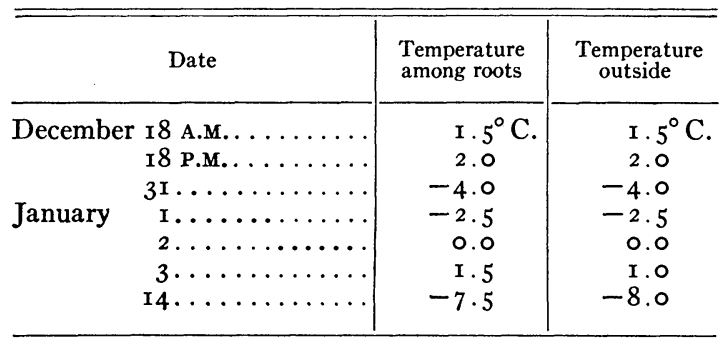

While the factor data will be discussed in connection with the transpiration graphs, it may be said here that at no time was the soil in the containers frozen solidly to a depth greater than 2.53.0 inches, a point extending not far into the root zone.

Transpiration losses were determined by weighing the containers. A large long-armed Troemner balance was used which was sensitive to $0.5 \mathrm{gm}$. under the maximum load of about 8-9 $\mathrm{kg}$. imposed upon it. In making the weighings the containers were transferred from their place out of doors into a weighing room cooled to nearly a similar temperature, for, as shown by WINKLER (23), leaves of evergreens and twigs of other trees can endure from four to six times as much cold if the changes are gradual as if they are sudden. Unless the water loss was rather insignificant as compared with the amount of soil concerned, the practice followed was to replace the loss at each weighing by adding the proper amount of water from a burette through the temporarily uncorked glass tube in the side of the container. Thus the soil moisture was kept at an almost uniform condition throughout. 
At least two or three times during the course of the experiments, which extended from September I9I7 to May 19I8, the seal was broken and the soil thoroughly aerated by means of an aspirator. An examination of containers discarded from time to time because of accidents to the aerial parts of the plants showed that at all times the soil was sweet and in good condition. Such an examination also revealed that the roots of both deciduous and coniferous trees had penetrated somewhat into the new soil. As pointed out by MACDougal (14), the root growth of broad-leaves corresponds to the warm periods during which absorption is active, while any

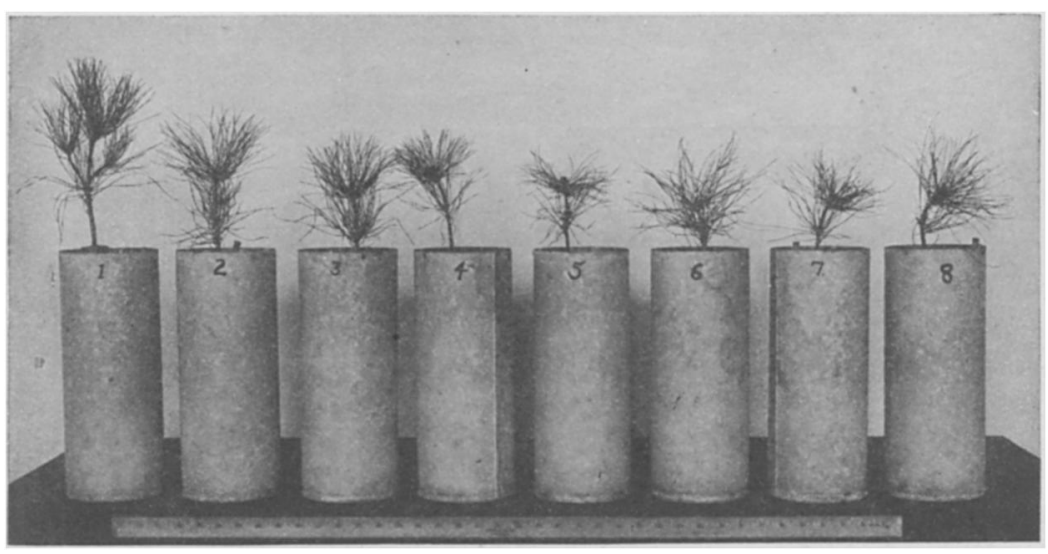

FIG. 2.-Battery of 3-year-old yellow pines; photographed February 28, I9I8; none of needles fallen.

possible resting period in summer is deemed due to scarcity of water and not to any inherent tendency of the plant toward a periodicity in growth.

\section{Pinus ponderosa}

Eight 3-year-old seedlings of yellow pine were repotted, as already described, into the metal containers 5.5 inches in diameter and 14 inches deep, and the first weighings were made on September 24. This battery is shown in fig. 2. The total leaf area was determined for several of the plants the following spring and at the end of the experiment. This ranged from a minimum of $2.905 \mathrm{sq}$. dm. in plant no. 7 , to a maximum of $6.428 \mathrm{sq} . \mathrm{dm}$. in plant no. I 
(fig. 2). The areas were determined by removing the leaves from the plants, measuring the length of the leaf fascicle and the average diameter of the flat faces, as well as the diameter of the cylinder formed by the two or three leaves in the fascicle when the flat faces were appressed against each other. From these data the actual surface area was calculated. Practically no needles were shed during the winter.

Fig. 3 shows the total average daily losses of six yellow pines from September 24 to January I. An examination of these graphs reveals a striking similarity. The highest losses are from tree

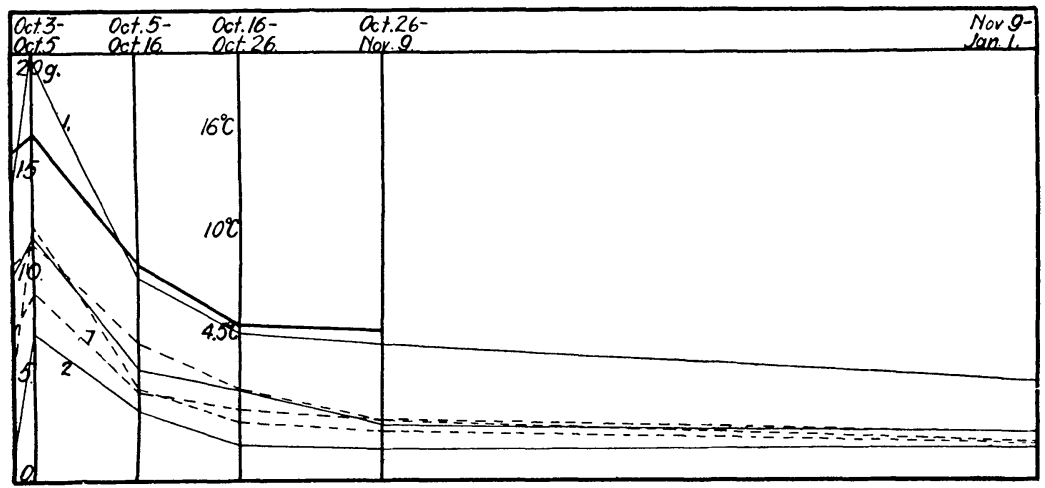

Fig. 3.-Average daily losses in grams from six 3 -year-old yellow pines from September 24 to January I; heavy line represents mean temperature for the several periods.

no. I with the greatest leaf area $(6.428$ sq. dm.), while the lowest losses are plotted from data obtained from tree no. 2, which had an area of only 4.r sq. dm. Comparative losses per unit area are given elsewhere. Data from the other two pines were omitted in this figure for the sake of clearness. A general relation between temperature and transpiration was clearly evident. The relation to humidity was not so apparent.

The entire period from September 24 to October 16 is characterized by relatively high transpiration losses, after which there is a decided falling off. On October I I the stomata were found to be closed. The midwinter transpiration losses are exceedingly small. Weighings made on February 7 and after a period of prolonged cold 
weather (the mean monthly temperature of January being only I $2.6^{\circ} \mathrm{F}$.) gave total maximum losses for the entire period of 37 days of only $2.5 \mathrm{gm}$. The average total loss during this time was about I gm. It is surprising how an area of $3-6 \mathrm{sq}$. dm. of leaf surface can be exposed with such minimum losses. The daily losses, compared with those from the same plants during the period September 24 to October I I, are only I/25I as great. The average losses during succeeding intervals are shown in table II.

TABLE II

TOTAL AMOUNT (IN GM.) OF WATER TRANSPIRED BY 3-YEAR-OLD YELLOW PINES FROM JANUARY I TO MAY 2, I9I8

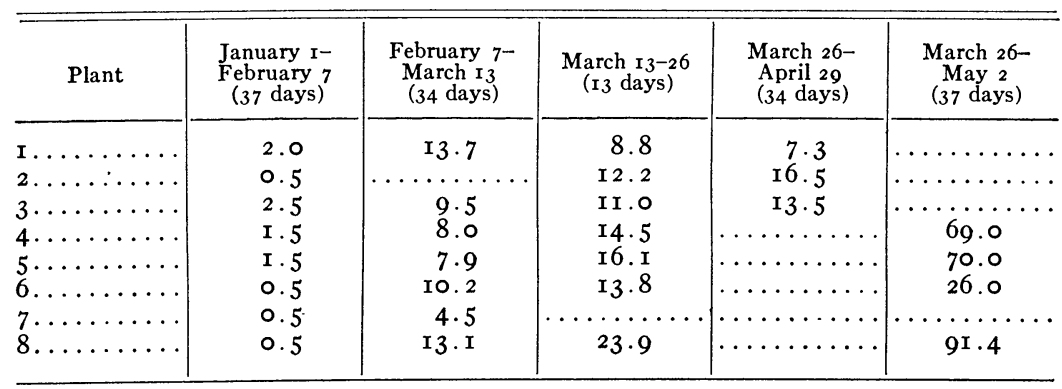

A general but slow rise during the cold month of April may be noted, with a sharp increase following the milder weather in May. The transpiring area throughout is practically constant, since little growth occurred before May I. On April 3 the stomata were found to be open.

Initial weighings from a battery of five 2-year-old yellow pines, each in a $4 \times 9$-inch container, were obtained on October 18 . Two of these plants are shown in fig. I2. Table III gives the total losses during the several periods.

On December ig the leaves were falling so badly that all but two plants were discarded, but the following spring all put out new leaves.

The exceedingly low water losses during the period December I9 to March I3 correspond with those found for the other battery of older yellow pines; in fact, this was found to be the case with all of the conifers. Table III shows an increase in the transpiring 
power as spring advanced similar to that of the older pines in the other battery. These plants were growing in a soil with an average water content of $\mathrm{I} 5.8$ per cent (I8.2 per cent maximum,

TABLE III

TOtal TRANSPIRATION LOSSES (IN GM.) OF 2-YEAR-OLD YELLOW PINES FROM OCTOBER I8 TO MAY 2

\begin{tabular}{|c|c|c|c|c|c|}
\hline Plant & $\begin{array}{c}\text { October 18- } \\
\text { November } 17 \\
\text { (30 days) }\end{array}$ & $\begin{array}{l}\text { November I7- } \\
\text { December I9 } \\
(32 \text { days })\end{array}$ & $\begin{array}{l}\text { December I9- } \\
\text { March I3 } \\
\text { (84 days) }\end{array}$ & $\begin{array}{l}\text { March I } 3- \\
\text { April } 2 \\
\text { (20 days) }\end{array}$ & $\begin{array}{l}\text { April 2- } \\
\text { May 2 } \\
\text { (30 days) }\end{array}$ \\
\hline $\mathbf{I} \ldots \ldots \ldots$ & 44.0 & I 2.0 & & & $\cdots$ \\
\hline $2 \ldots \ldots \ldots \ldots$ & 48.0 & I4. I & $\ldots \ldots \ldots$ & $\ldots \ldots \ldots$ & ........ \\
\hline $3 \ldots \ldots \ldots$ & 42.0 & 4.0 & $\ldots \ldots$ & $\therefore$ & $\ldots \ldots \ldots$ \\
\hline $4 \ldots \ldots \ldots$ & 17.6 & $6 . \mathrm{I}$ & $4 \cdot 3$ & 8.2 & I 3.6 \\
\hline $5 \ldots \ldots \ldots \ldots$ & 22.5 & 6.5 & $3 \cdot 4$ & 6.3 & I 2.5 \\
\hline
\end{tabular}

I4. 6 per cent minimum), and an available water content varying from 13.5 to ro per cent.

\section{Pinus Banksiana}

A battery of eight 3-year-old jack pines in containers 4.5 inches in diameter and ro inches deep was sealed and weighed on September 26 . These trees were growing in a soil with an actual water content ranging from 8.6 to 15 . I per cent, of which only 4 and I0. 3 per cent respectively were available for growth.

The leaf area, calculated in a manner similar to that already described for the yellow pines, ranged from 2. I4I to 4.470 sq. dm. The plants remained in good condition throughout the winter and showed vigorous growth in the spring. In addition to the usual brownish color of the leaves in winter, however, the tips of many of the leaves died during January and February. Practically all the leaves remained on the plants throughout the experiment. Fig. 4 shows this battery as it appeared on February 28 .

The transpiration losses as determined for the several periods are plotted in fig. 5. A glance at these graphs shows two things which are at once apparent. First, the general parallelism of the lines throughout (except from October i 7 to 26 , to be considered later); that is, the plant which gave the highest or lowest losses during the early periods continued this behavior throughout. The 
actual losses are generally correlated with the leaf area; for example, the greatest losses are from plant no. 7 with an area of $4.47 \mathrm{sq}$. dm., while those in graph no. 2 are from a plant with an area of only 2.I4 sq. dm. Secondly, there may be noted a rise or fall in the graphs which corresponds in general with temperature changes. After October 17 there was a gradual but marked falling off in water

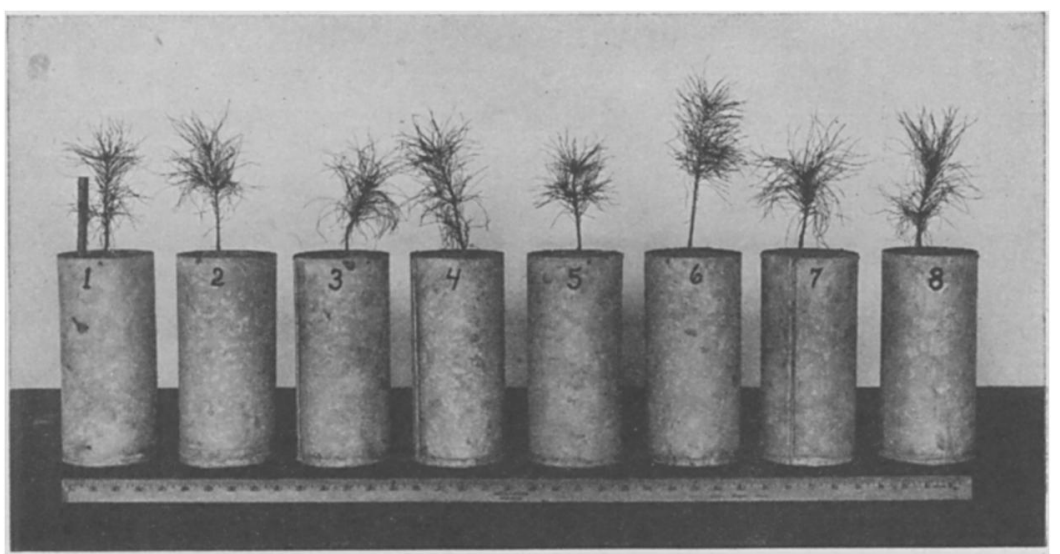

Fig. 4.-Battery of 3-year-old jack pines

losses, and the rate remained very low until about the first week in April, when growth was resumed. These data are shown in table IV.

\section{TABLE IV}

Total transpiration LOSSES (IN GM.) FROM 3-YEAR-OLD JACK PINES DURING THE SEVERAL INTERVALS FROM DECEMBER I9 TO APRIL 29

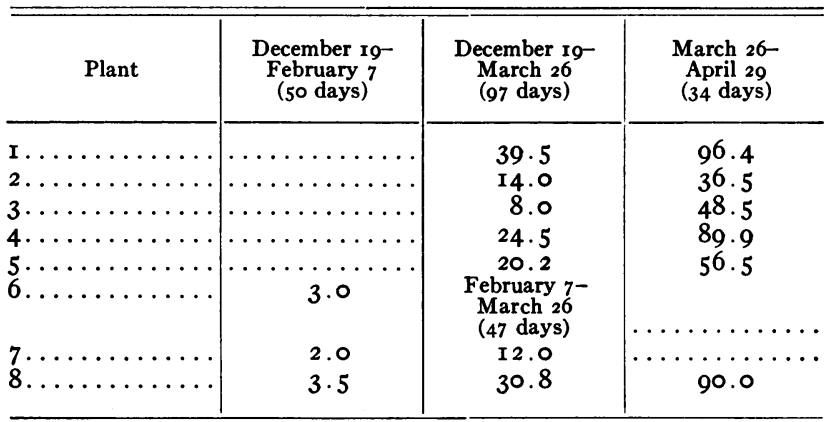


The midwinter losses, actual and relative, are just as marked as they were in the case of the yellow pines. During the period December 19 to February 7 the total average loss was only $2.8 \mathrm{gm}$., an amount which, compared on the daily basis, is only $\mathrm{I} / \mathrm{r} 69$ of that lost during the autumn period (September 26 to October I 7 ).

\section{Abies grandis}

Two batteries of white firs were used. One consisted of eight 2-year-old seedlings in containers 3.5 inches in diameter by 6.5 inches deep, and the other of eight 4-year-old trees in containers 3.5 inches in diameter and 9 inches deep.

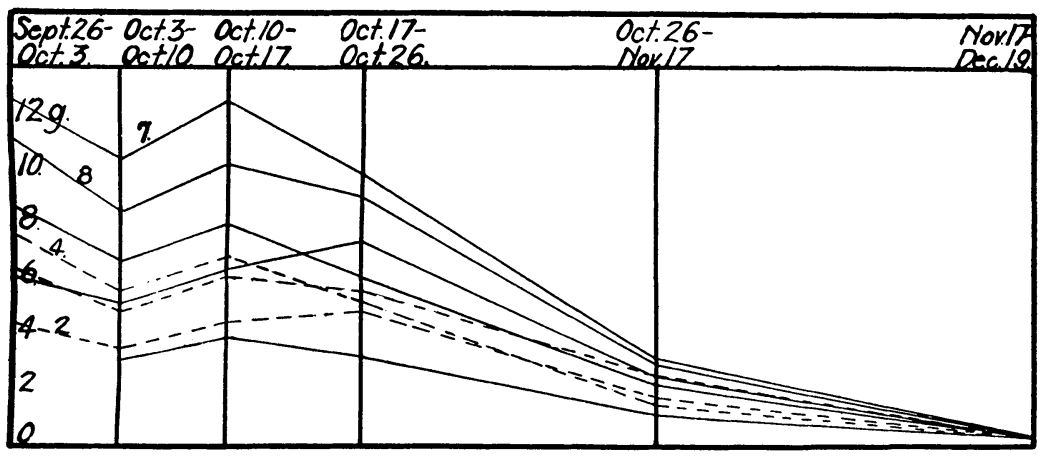

FIG. 5.-Average daily losses in grams from eight 3-year-old jack pines; September 26 to December I9, I9I7.

The younger plants were growing in soil with an available water content ranging from 6 to 9.4 per cent. All were winter killed. As this did not occur until January or February, the transpiration losses up to that time are reliable. About January I 5 the leaves began to drop off badly, but the leaf area of several of the plants was determined without removing the leaves, and before defoliation had begun. This was accomplished by determining the number of leaves, their lengths, and average diameters. Three of these seedlings had leaf areas of $0.0972,0.164 \mathrm{I}$, and $0.0970 \mathrm{sq}$. dm. respectively. These plants are shown in fig. II. This picture was taken late in February after many of the leaves had fallen. Because of an accident to the top of one tree, it was discarded. 
The transpiration losses from September 27 to December I 2 from the seven remaining plants are shown in fig. 6 . The average total loss during the period of December I 2 to February II was only $0.7 \mathrm{gm}$., the maximum and minimum losses being 1.0 and $0.3 \mathrm{gm}$. respectively. This daily winter loss compared with that of early fall (September 27 to October Io) is only I/55 as great. It must be noted, however, that it was during this period that the seedlings were winter killed and may have lost more water than

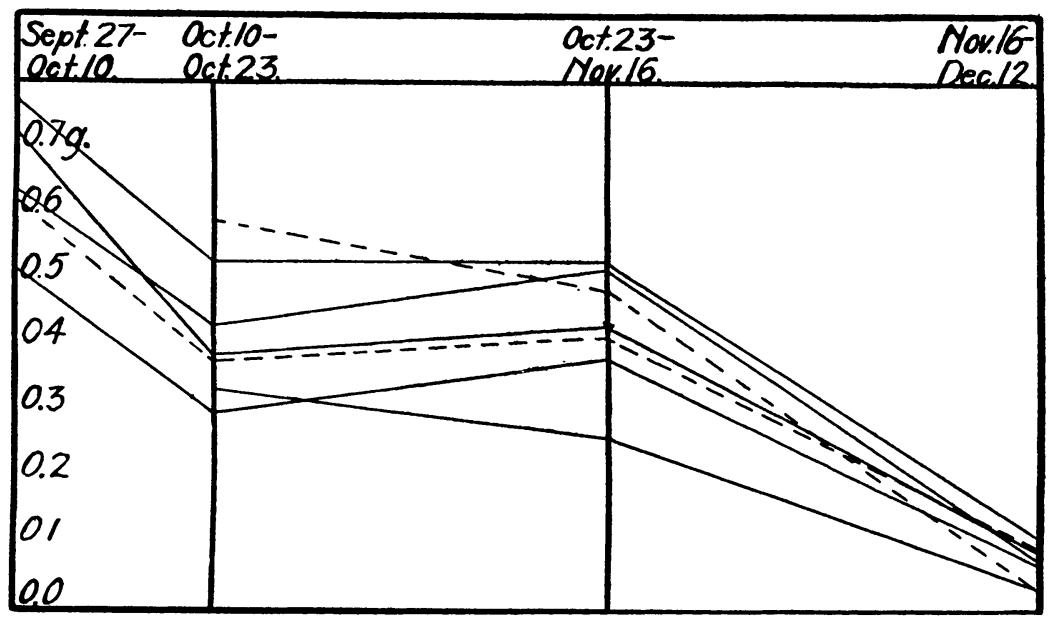

FIG. 6.-Average daily losses in grams from seven 2-year-old white firs from September 27 to December I2, I9I 7 .

normally. On February i I the leaves were brown and the plants appeared dead.

The 4-year-old firs, although growing under more favorable moisture conditions (from 5.3 to 13.7 per cent available moisture), also succumbed to the dry cold winter. On February i i the leaves were all brown and dead. The transpiration losses to December 19 are reliable, however, for up to this time all the plants were in good condition. The leaves did not drop badly, even after drying, as is shown in fig. 7, a photograph which was taken on February 28. Leaf areas for plants 5 and 6 were calculated as for the other white firs. These leaf areas were $\mathrm{I} .065$ and $0.638 \mathrm{sq}$. dm. respectively. 
Since weighings of both sets of firs were taken on the same days, the graphs in fig. 6 may be compared directly with those in fig. 8 .

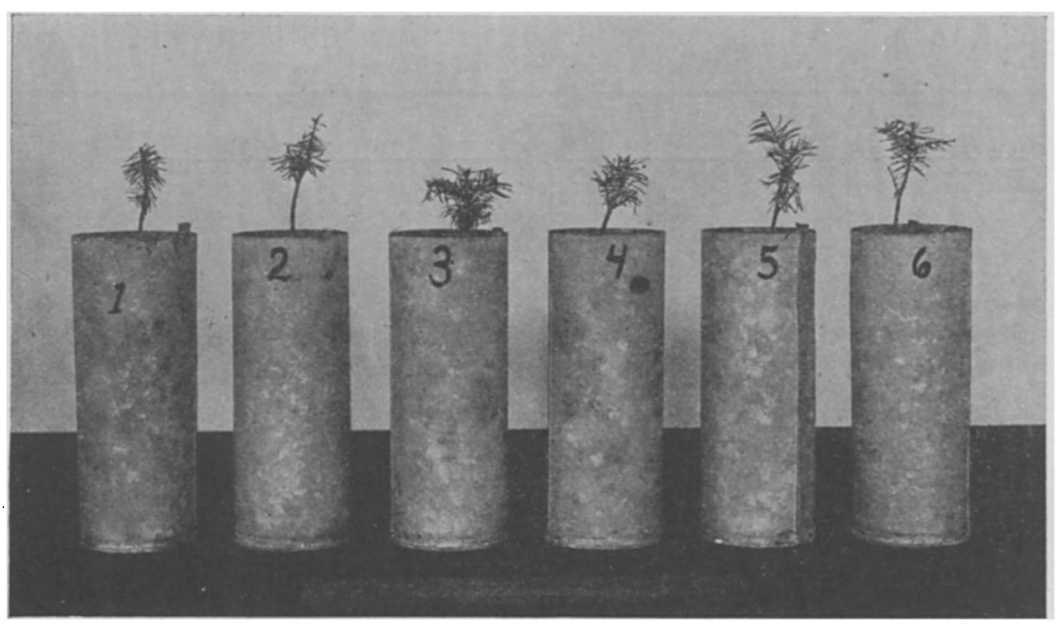

Fig. 7.-Battery of 4-year-old white firs; photographed February 28, I918, after some of leaves had fallen.

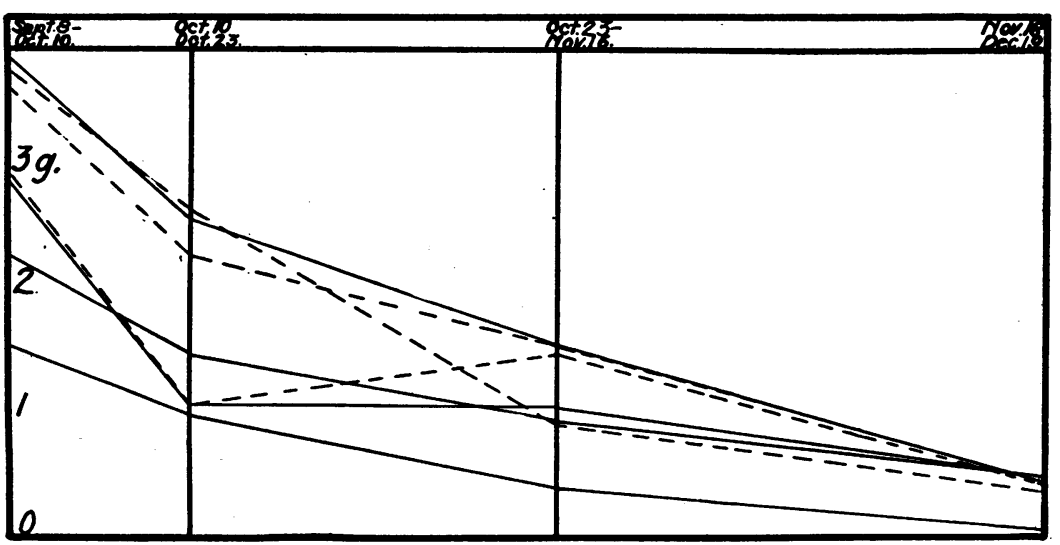

FIG. 8.-Average daily losses in grams from battery of seven 4-year-old white firs; September 28 to December 19, I917.

A marked irregularity in the course of the otherwise generally parallel graphs may be seen during the period of October 23 to November 16 . 
Attention has already been called to this phenomenon in case of both the yellow and jack pines, and figs. 9 and Io show the same occurrence for the spruce and Douglas fir. Although this phenomenon was not examined carefully at the time, for it was not known

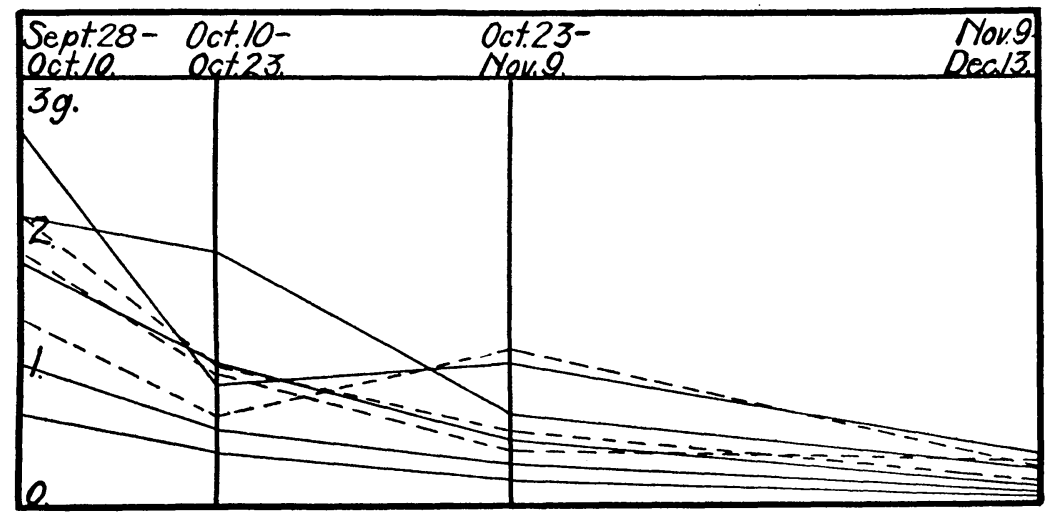

FIG. 9.-Average daily losses in grams from battery of eight 3-year-old spruces; September 28 to December I3, I9 7 .

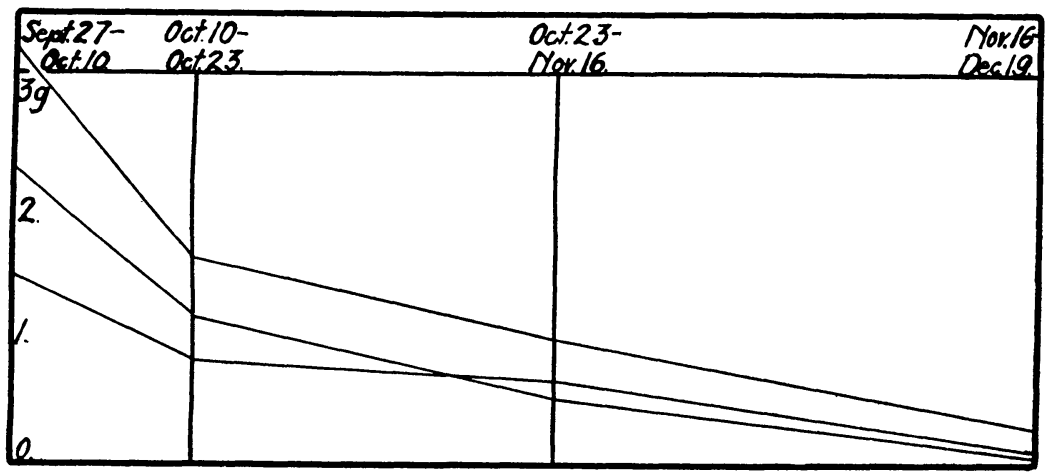

FIG. I0.-Average daily losses in grams from battery of three 3-year-old Douglas firs; September 27 to December I9, I9r7.

to occur until after the final weighings on November I 6 were plotted, the irregularity is probably due to the individuality shown by the several plants in the rapidity of permanent closure of the stomata, and a general slowing down of the vital activities as the temperature decreased. 


\section{Picea Engelmanni}

This battery consisted of eight 3-year-old Engelmann spruce seedlings grown in containers 3.5 inches in diameter by 6.5 inches in depth, and in soil with available moisture ranging from II.3 to I5 . I per cent.

Although the leaves dropped off badly during late December and in January, none of the plants died. All put forth a vigorous growth of new leaves during April and May of the following spring. Three of these trees, photographed in February, are shown in fig. II.

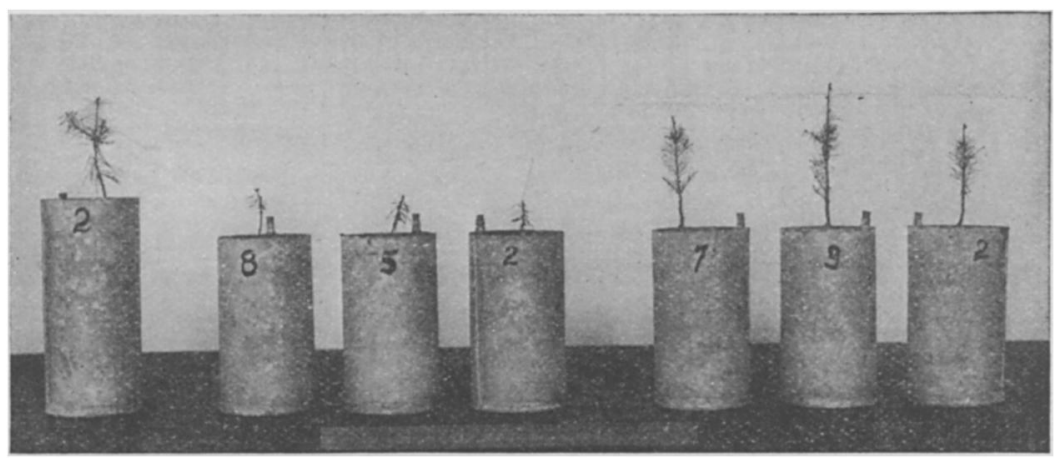

Fig. I1.-Three 3-year-old Engelmann spruces, three 2-year-old white firs, and one Douglas fir, all more or less defoliated; photograph taken February 28, r918.

The leaf areas of three plants, calculated at the time the leaves had just begun to fall, were $2.78,3.9 \mathrm{I}$, and $5.87 \mathrm{sq}$. dm. respectively. These areas were determined while the leaves were still intact by counting their total number, measuring the length and average diameter of each leaf, and then calculating the area of the four sides. The graphs giving the transpiration losses are shown in fig. 9. A comparison of the water losses from these plants with those of other conifers shows a remarkable similarity.

\section{Pseudotsuga mucronata}

Because of high mortality among the Douglas firs during the reestablishment in pots in early summer, only three 3-year-old seedlings were available for experimental work in September. These were placed in containers 3.5 inches in diameter by 8 inches 
in depth, sealed and weighed on September 27. The water content of the soil in the three containers was $\mathrm{I}_{3} .8, \mathrm{I} 5$, and $\mathrm{I} 8$ per cent respectively. The wilting coefficient was $4 \cdot 7$. One of these plants is shown in fig. II.

The leaf area of plant no. I was $0.3062 \mathrm{sq}$. dm. This was determined by considering the leaves as having two flat surfaces and multiplying the length of each by its average diameter.

Transpiration losses are shown from September 27 to December I9 in fig. Io. During the period December is to February II, the total losses of two plants (the third having accidentally been

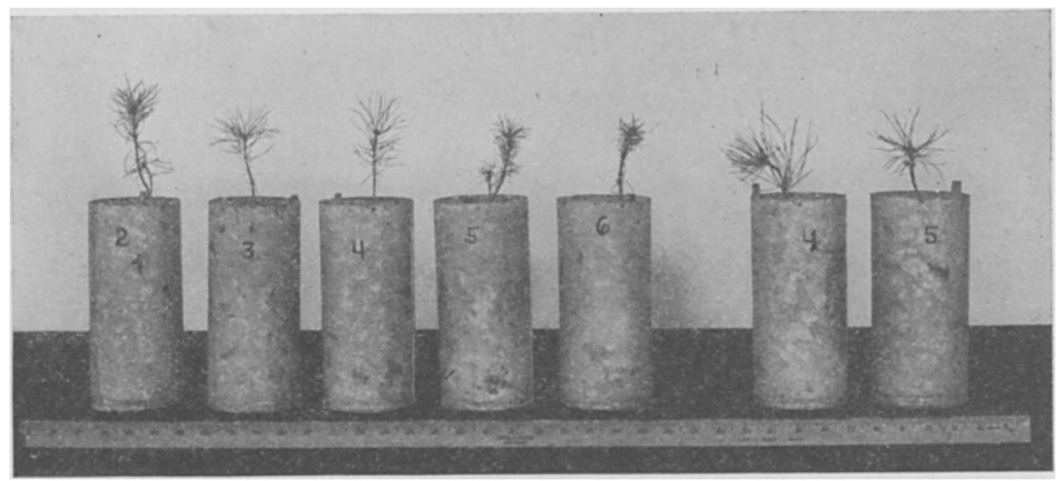

FIG. 12.-Battery of five 3-year-old lodge pole pines and two 2-year-old yellow pines; photographed February 28, I918.

broken off) were 0.4 and I. I gm. respectively. On the basis of the average daily loss, this is a mere fraction (only I/146) of that during the autumn period September 27 to October Io. In March the plants were discarded because of the falling leaves; in fact, one finally died, but the others showed renewed growth in the spring.

\section{Pinus Murrayana}

Still another battery of needle-leaved plants, consisting of six 3-year-old lodge pole pines, was experimented upon during the period beginning October 18 . These plants, grown in containers 4 inches in diameter and 9 inches in depth, are shown in fig. I2. The water content of the soil ranged from 16.4 to $2 \mathrm{I} .8$ per cent. 
All of the plants died in February, although the needles persisted for a long time.

The transpiration losses shown in table $\mathrm{V}$ are not greatly different in their amount from those of the other conifers. Likewise they show a gradual decrease as winter approaches, with minimum midwinter losses. All losses recorded are reliable because no readings were taken after the plants showed signs of deterioration.

TABLE V

Total LOSSES (IN GM.) FROM A BATTERY OF SIX LODGE POLE PINES FROM OCTOBER I8 TO FEBRUARY II

\begin{tabular}{|c|c|c|c|c|}
\hline Plant & $\begin{array}{c}\text { October I 8- } \\
\text { October } 26 \\
\text { (8 days) }\end{array}$ & $\begin{array}{l}\text { October 26- } \\
\text { November } 17 \\
\text { (22 days) }\end{array}$ & $\begin{array}{c}\text { November I 7- } \\
\text { January } 4 \\
\text { (48 days) }\end{array}$ & $\begin{array}{c}\text { January 4- } \\
\text { February II } \\
\text { (38 days) }\end{array}$ \\
\hline $\begin{array}{l}1 \ldots \ldots \\
2 \ldots \ldots \ldots \\
3 \ldots \ldots \ldots \\
4 \ldots \ldots \ldots \ldots \\
5 \ldots \ldots \ldots \ldots \\
6 \ldots \ldots \ldots \ldots \\
6 \ldots \ldots \ldots \ldots\end{array}$ & $\begin{array}{r}4 \cdot 5 \\
\mathrm{I} 3 \cdot 4 \\
2 \cdot 9 \\
5 \cdot 3 \\
7 \cdot 5 \\
\mathrm{I} \mathrm{I} \cdot 5\end{array}$ & $\begin{array}{r}9 \cdot 5 \\
30.4 \\
\mathrm{I} 5 \cdot 5 \\
\mathrm{I} 3 \cdot 5 \\
\mathrm{I} 5 \cdot 5 \\
37 \cdot 7\end{array}$ & $\begin{array}{r}3 \cdot 9 \\
6.0 \\
5 \cdot 5 \\
2.6 \\
7.8 \\
\mathbf{I} \cdot 3\end{array}$ & $\begin{array}{l}0.7 \\
0.7 \\
1.6 \\
0.7 \\
1.1 \\
1.0\end{array}$ \\
\hline
\end{tabular}

\section{Ulmus americana}

Initial weighings of a battery of $\mathrm{I} 2$ white elm trees were made on September 20. These plants were in containers 5.5 inches in diameter and 8.5 inches deep. A photograph taken on May I just when the plants were leafing out is shown in fig. I3.

The leaf areas were determined, as in the case of the other dicotyledons, by means of solio leaf prints. These were made, of course, without removing the leaves from the stems. The areas of the plants whose transpiration losses are shown in fig. I4 were as follows:

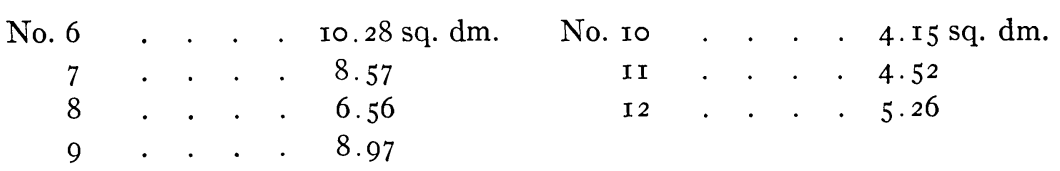

For the sake of clarity, the losses from the other plants were not recorded in fig. I4. In all cases they were very similar. With the exception of plant no. I2, there is a close agreement between 


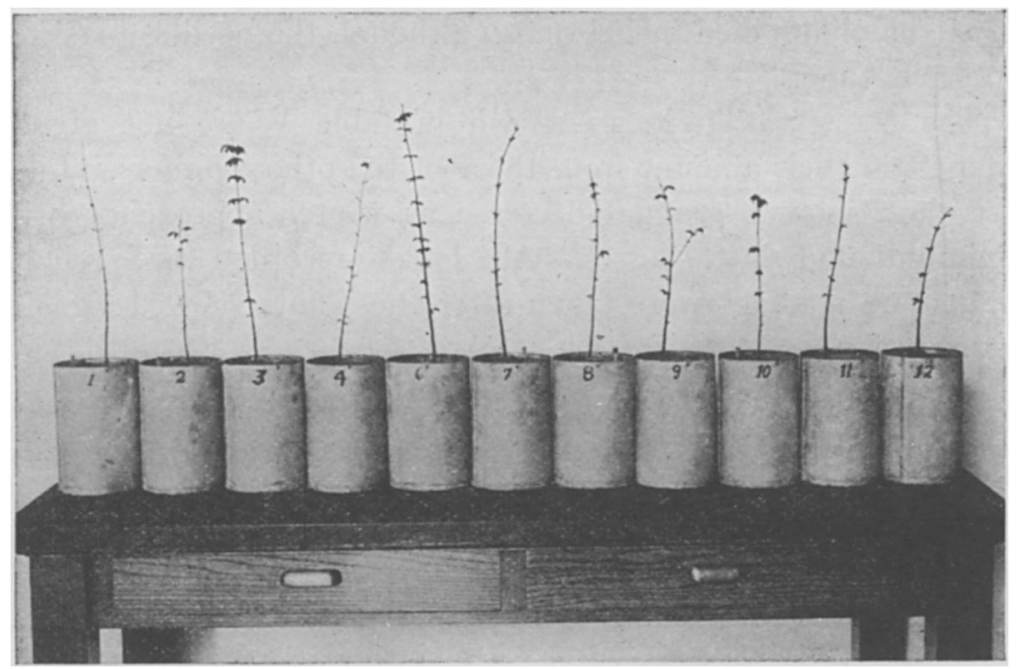

FIG. 13.-Battery of white elms putting out new leaves; photographed May I

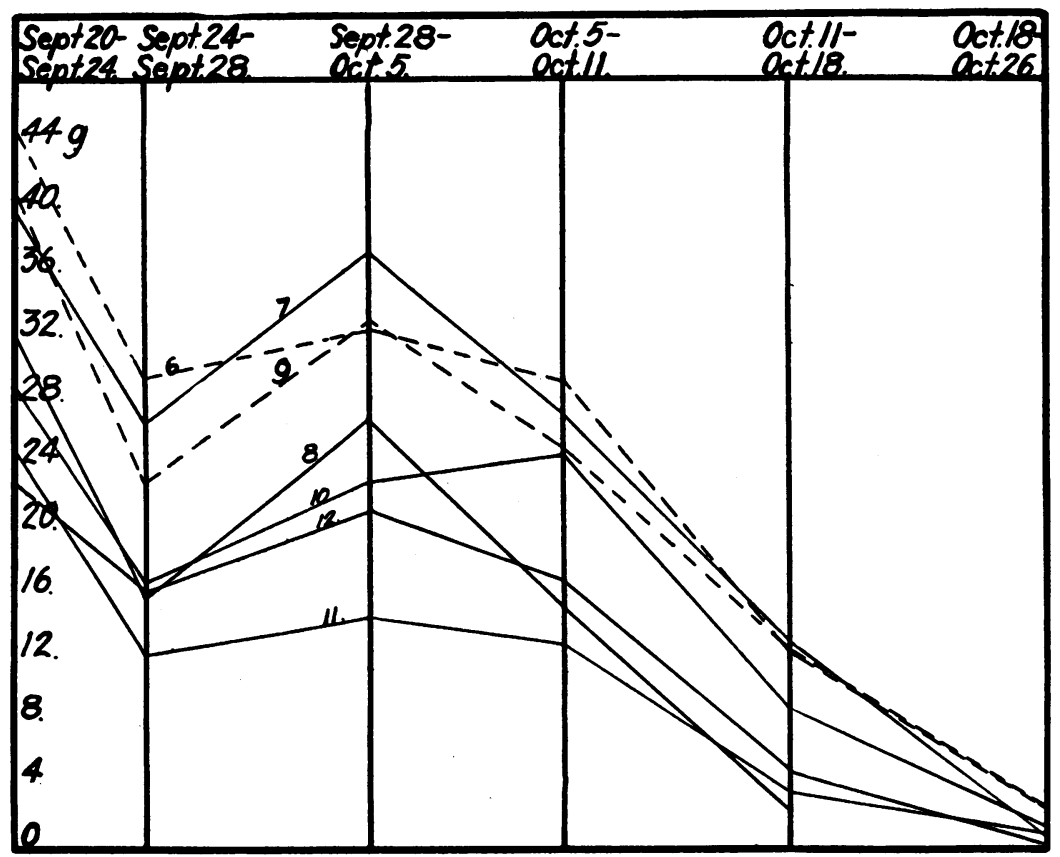

Fic. I4.-Average daily losses in grams from seven r-year-old elm trees; September 20 to October 26 , I9r 7 . 
the early autumn losses (September 20 to October II) and the initial leaf area. Also a comparison of the graph of mean temperature for the several periods (fig. I5), with the graphs showing the march of transpiration, shows that they have a striking resemblance. The mean temperature was obtained from the thermograph records, and is given on a time-humidity basis. The means for the several periods respectively were obtained by drawing a horizontal line through the weekly record sheet in such a manner that the total area included by the graph above this line was equal to the total area below the line. The areas were determined by the aid of a planimeter. In this interpretation both temperature and time factors are taken into consideration. Temperature, indeed, seems to be the controlling factor, for no such correlation between transpiration and humidity (here the graph is inverted) is discernible after October 5; that is, transpiration dropped off at this time, following the descending temperature graph in spite of a decreasing humidity.

These two factors, however, together with wind velocity, are well summed up in evaporimeter readings. These were obtained by Livingston's porous cup atmometers and show an increase or decrease very similar to the transpiration graphs. They are as follows:

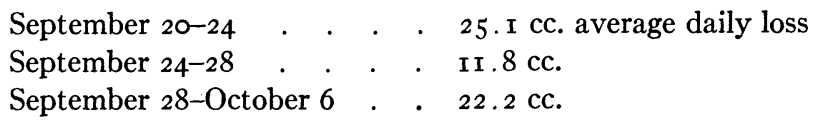

Readings were discontinued on October I I because of freezing weather at night. Unfortunately no instrument has yet been devised for satisfactorily measuring winter evaporation losses.

The irregularity in the graphs, especially in the fourth interval, is due to the non-uniform drying out of the leaves. Up to October 5 the leaves of all the dicotyledonous plants were green and apparently functioning normally. By October i I a few of the older basal leaves were beginning to turn brown. While some dropped at once, many held on after they were dry. This irregularity in defoliation defeated an attempt to base the daily losses upon the actual average leaf area during any given period, although an exact 
record was kept of the time of the fall of each leaf, together with its area.

The transpiration graphs show a general falling off after October II, which is not unlike that of the conifers; only here the transpiration is from a constantly decreasing area (all the leaves had fallen or remaining fragments were removed by October 26), while in the conifers the area remains constant. In table VI are given the total losses (which are too small to plot on an average daily basis) from October 26 to May i.

TABLE VI

Total LOSSES (IN GM.) FroM I 2 ELM TREES From OCTOBER 26 TO MAY I

\begin{tabular}{|c|c|c|c|c|}
\hline Plant & $\begin{array}{c}\text { October } 26- \\
\text { November } 9 \\
\text { (I4 days) }\end{array}$ & $\begin{array}{c}\text { November } 23- \\
\text { January } 4 \\
\text { (42 days) }\end{array}$ & $\begin{array}{c}\text { January 4- } \\
\text { April 24 } \\
\text { (I IO days) }\end{array}$ & $\begin{array}{c}\text { April 24- } \\
\text { May I } \\
\text { (7 days) }\end{array}$ \\
\hline I $\ldots \ldots \ldots$ & $\ldots \ldots \ldots \ldots$ & I.O & $7 \cdot 4$ & 2.2 \\
\hline $2 \ldots \ldots \ldots$ & $\ldots \ldots \ldots \ldots$ & I. 0 & 5.6 & 3.2 \\
\hline $3 \ldots \ldots$ & 6.9 & I.O & I 2.3 & I 2.7 \\
\hline $4 \ldots \ldots$ & 2.8 & 1.0 & 6.6 & 2.7 \\
\hline $6 \ldots \ldots \ldots$ & $3 \cdot 3$ & I. 0 & I I $\cdot 3$ & 9.7 \\
\hline $7 \ldots \ldots \ldots$ & $3 \cdot 4$ & I. 5 & 10. 8 & I. 3 \\
\hline $8 \ldots \ldots \ldots$ & 2.0 & 1.0 & 5.8 & 3.2 \\
\hline $9 \ldots \ldots \ldots$ & $5 \cdot 7$ & I. 5 & $9 \cdot 3$ & $3 \cdot 7$ \\
\hline Iо........ & I. 9 & 0.5 & 7.0 & 5.8 \\
\hline II $\ldots \ldots \ldots$ & 0.4 & 0.5 & $4 \cdot 5$ & 2.3 \\
\hline I $2 \ldots \ldots \ldots$ & I. 5 & 0.5 & 7.1 & 2.2 \\
\hline
\end{tabular}

From November 9 to 23 the seals were removed and the soil allowed to dry out. The loss was about I25-1 $75 \mathrm{gm}$. They were then resealed, and $250 \mathrm{cc}$. of water was added. On April 24 some of the plants, as nos. 2, Io, and I I, had buds swollen but not yet open, while in others, as nos. 3, 6, and 7 , the leaves were unfolding. On May I nos. 3 and 6 had leaves fairly well out, some of them being over $\mathrm{I} .5 \mathrm{~cm}$. long, while in others (as nos. I and 7 ) the leaves were just bursting from the buds.

The winter losses are very small. During a period of 42 days (November 23 to January 4) the average loss was only I gm. from the bare stems which exposed an area of 0.28 to $0.50 \mathrm{sq} . \mathrm{dm}$. Table IX gives the relative transpiration losses of conifers and broad-leaved trees. 


\section{Acer saccharinum}

Weighings of a battery of I 2 soft maples were made on the same dates as those for the elms. The containers were of the same size,

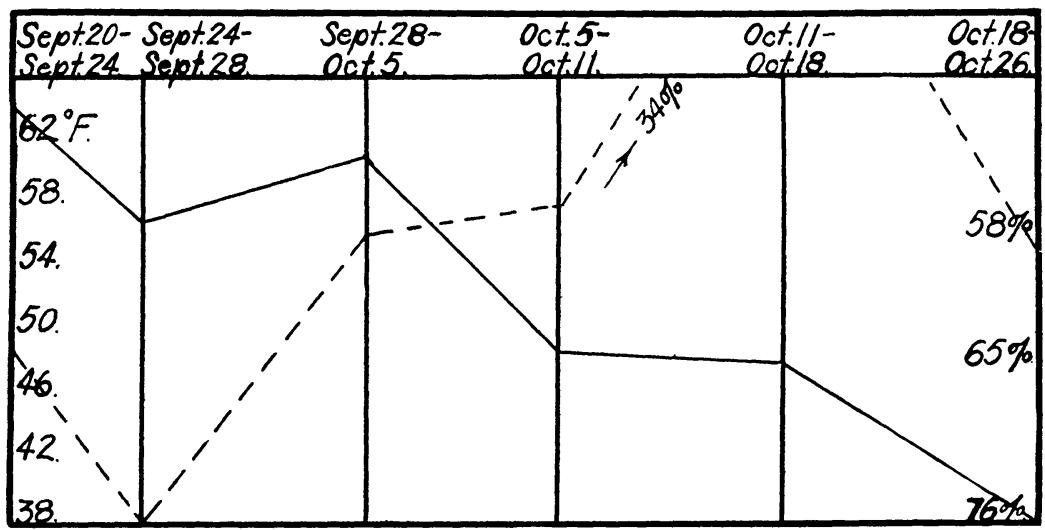

FIG. I5.-Mean temperature (solid line) and mean humidity (broken line) during several intervals from September 20 to October 26, I9 7 .

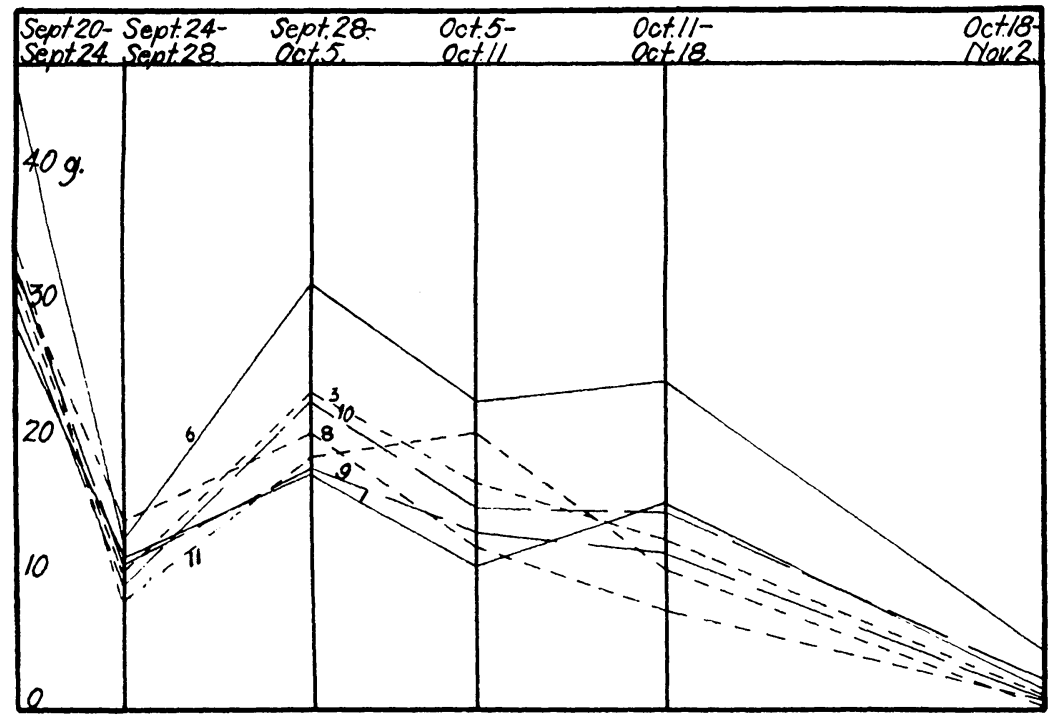

FIG. I6.--Average daily losses in grams from seven I-year-old maple trees; September 20 to November 2, I9I7.

and the batteries and the methods of handling them were so similar throughout that further description will be unnecessary. 
The leaf areas ranged from I I. 32 sq. dm. in plant no. 6, which gave the highest losses throughout (fig. I6), to $6.47 \mathrm{sq}$. dm. in no. II, where the transpiration losses are among the lowest. A good correlation existed between leaf area and the magnitude of the losses. To avoid confusing a multiplicity of lines, data from five of the maples have been omitted in this figure. The data of these five trees are very similar to those shown.

TABLE VII

TOtal LOSSES (IN GM.) FROM I 2 MAPLE TREeS FROM NOVEMBER 2 TO MAY I

\begin{tabular}{|c|c|c|c|c|c|}
\hline Plant & $\begin{array}{l}\text { November } 2-\mathrm{I} 6^{*} \\
\text { (I } 2 \text { days) }\end{array}$ & $\begin{array}{c}\text { November 28- } \\
\text { January I } \\
\text { (34 days) }\end{array}$ & $\begin{array}{c}\text { January I- } \\
\text { April 24 } \\
\text { (II3 days) }\end{array}$ & $\begin{array}{c}\text { April 24- } \\
\text { May I } \\
\text { (7 days) }\end{array}$ & $\begin{array}{l}\text { Condition on } \\
\text { on May } \mathbf{~}\end{array}$ \\
\hline $2 \ldots \ldots: \ldots$ & 2.2 & 0.8 & 2.9 & 3.6 & $\begin{array}{l}\text { Two buds un- } \\
\text { folding leaves }\end{array}$ \\
\hline $6 \ldots \ldots$ & 2.5 & 0.8 & $4 \cdot 5$ & 2.2 & $\begin{array}{l}\text { Just showing } \\
\text { signs of life }\end{array}$ \\
\hline $8 \ldots \ldots$ & 3.0 & I. I & & & $\ldots \ldots \ldots \ldots \ldots$ \\
\hline Iо........ & I. 7 & 0.3 & 3.6 & 70.1 & 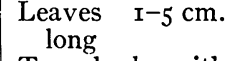 \\
\hline I $2 \ldots \ldots$ & $\begin{array}{c}\text { I.8 } \\
\text { December 6- } \\
\text { January I } \\
\text { (26 days) } \\
\text { I.8 }\end{array}$ & 0.5 & $2 \cdot 3$ & I $3 \cdot 5$ & $\begin{array}{l}\text { Two buds with } \\
\text { leaves } 2 \quad \mathrm{~cm} \text {. } \\
\text { long }\end{array}$ \\
\hline $3 \ldots \ldots$ & $\underset{\text { (I4 days) }}{\text { November } 2-\mathrm{I} 6 *}$ & $\ldots \ldots \ldots \ldots$ & $3 \cdot 7$ & 4.0 & $\begin{array}{l}\text { One bud swollen; } \\
\text { two others } \\
\text { partly open } \\
\text { but frozen }\end{array}$ \\
\hline $\begin{array}{l}5 \ldots \ldots \ldots \\
7 \ldots \ldots \ldots\end{array}$ & \begin{tabular}{l|} 
I. 5 \\
2.0
\end{tabular} & $\begin{array}{l}0.9 \\
1.8\end{array}$ & ${ }^{\ldots \ldots \ldots \ldots}$ & $\begin{array}{l}\ldots \ldots \\
\ldots \ldots \ldots\end{array}$ & 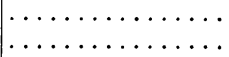 \\
\hline $9 \ldots \ldots$ & I. 5 & I. 0 & $\cdots \cdots$ & $\ldots \ldots$ & $\ldots \ldots \ldots \ldots \ldots \ldots$ \\
\hline II $\ldots \ldots$ & 2.5 & 0.5 & $\ldots$ & $\ldots \ldots$ & $\ldots \ldots \ldots \ldots \ldots$ \\
\hline
\end{tabular}

* All leaves off.

As in the case of the elms, a close correlation exists between transpiration, evaporation, and temperature (fig. I5); in fact, the general trend of the graphs is strikingly similar to those of the elms. The same irregularity is shown during the period of defoliation. On October 26 only the bare stems remained; these had a surface area of $0.22-0.48 \mathrm{sq}$. dm.

Further losses from November 2 to May I are given in table VII. The small losses are again evident, followed by a rapid rise 
accompanying the unfolding of the buds. Six plants were winter killed, and no losses were recorded for them after January I.

\section{Quercus macrocarpa}

A number of bur oak seedlings were grown from acorns obtained from an Illinois nursery in May r 9 r 7 . Seven of the lot were finally selected for experimental work. These were repotted in containers 5 inches in diameter and 7 inches deep. They may be seen in the foreground in fig. I. The initial available water content of the soil ranged from II.3 to I 5.2 per cent, but the soil moisture was reduced by evaporation from the surface of the several containers

TABLE VIII

Average daily losses (In gm.) of bUr oAK Seedlings from September 24 to JANUARY 4

\begin{tabular}{|c|c|c|c|c|c|}
\hline Plant & $\begin{array}{c}\text { September }{ }^{24-} \\
\text { October } 3 \\
\text { (9 days) }\end{array}$ & $\begin{array}{l}\text { October } 3-\text {-ro } \\
\text { (7 days) }\end{array}$ & $\begin{array}{c}\text { October ro-r } 8 \\
\text { (8 days) }\end{array}$ & $\boldsymbol{N}_{\text {(1 } 5 \text { days) }}^{\text {November } \mathrm{I}-\mathrm{r} 6 *}$ & $\begin{array}{c}\text { December } 7^{-} \\
\text {January }{ }^{4} \\
(28 \text { days })\end{array}$ \\
\hline I $\ldots \ldots \ldots$ & 9.0 & 7.0 & $2 . I$ & 0.25 & I.O \\
\hline $2 \ldots \ldots \ldots$ & $\ldots \ldots \ldots \ldots$ & II.O & 4.9 & 0.55 & I. 3 \\
\hline $3 \ldots \ldots \ldots$ & IO. 2 & 6.4 & $4 \cdot 3$ & I. 22 & I . 4 \\
\hline $4 \ldots \ldots \ldots$ & I $5 \cdot 5$ & 9.9 & I . I & 0.26 & I. 8 \\
\hline $5 \ldots \ldots \ldots$ & 7.2 & $3 \cdot 4$ & 0.4 & $0.2 \mathrm{I}$ & I.O \\
\hline $6 \ldots \ldots \ldots$ & $4 \cdot 5$ & 2.6 & 0.5 & 0.28 & I.O \\
\hline $7 \ldots \ldots \ldots$ & $\mathrm{I}_{5} \cdot 2$ & I 2.9 & 8.0 & I. 89 & I . 8 \\
\hline
\end{tabular}

* At this time all the leaves had fallen, and the losses are not calculated on the average daily basis, but on the total loss for the entire period.

to a minimum of 4.4 and a maximum of 9.6 per cent respectively from October I 8 to November I. After this the seals were again replaced and half of the containers brought back to the original water content. The transpiration losses are shown in table VIII.

The gradual falling off in the transpiration rate without any increase, as in the case of the elms and maples, may be explained by an examination of the dates, which show that the first loss was not recorded until a time (October 3 ) when all the trees show a steady decrease. By November I all of the leaves had fallen (or the dried leaves were removed). Following this the losses are extremely small. The stem areas of the oaks were only $0.039^{-}$ $0.088 \mathrm{sq} . \mathrm{dm}$. 


\section{Relative transpiration rates}

Thus far we have considered largely transpiration losses of different individuals of the batteries of the various species, with only occasional reference to comparative losses of different species. It may be well, therefore, to present data showing the actual losses of different species based upon unit area. These data have been summarized in table IX. While the dates between readings are not synchronous in all cases, they are at least nearly so, and fig. I5,

TABLE IX

COMPARATIVE TRANSPIRATION LOSSES FROM UNIT AREAS OF SURFACE OF BROADLEAVED AND EVERGREEN TREES

\begin{tabular}{|c|c|c|c|c|c|}
\hline Species & $\begin{array}{l}\text { No. of } \\
\text { trees }\end{array}$ & \multicolumn{3}{|c|}{ Time } & $\begin{array}{l}\text { Average. loss per } \\
\text { sq. dm. per day }\end{array}$ \\
\hline Acer saccharinum .......... & 9 & September & $24-$ October & 5 & 2.66 \\
\hline Ulmus americana........... & 9 & & $24^{-} " “$ & 5 & $3 \cdot 5^{6}$ \\
\hline Quercus macrocarpa......... & 7 & $"$ & $24^{-}$ & 3 & $5 \cdot$ I 8 \\
\hline Picea Engelmanni. . . . . . . . . . & 3 & " & $28-$ & Io & 4.18 \\
\hline Abies grandis ( 2 years old)..... & 3 & " & $27^{-}$ & IO & $5 \cdot 44$ \\
\hline Abies grandis (3 years old)..... & 2 & " & $28-$ & I I & $4 \cdot 76$ \\
\hline Pinus ponderosa........... & 3 & " & $24-$ & 5 & 4.20 \\
\hline Pinus Banksiana . . . . . . . . . & 3 & " & $26-$ & IO & 4.80 \\
\hline
\end{tabular}

which gives the temperature and humidity, together with the record from the atmometers, shows that the overlapping periods are quite uniform.

\section{Relative midsummer transpiration rates of broad-leaved trees and conifers}

During the following summer, while the writers were carrying on other investigations in the Rocky Mountains of the Pike's Peak region of Colorado, opportunity was afforded to compare the summer transpiration rates of different tree species.

Seedlings of white elm and soft maple grown from seed at the Alpine Laboratory near Manitou, Colorado, and at an altitude of $8000 \mathrm{ft}$., together with mountain maple (Acer glabrum Torr.) obtained from the forest, were the broad-leaved species used. Yellow pine, Douglas fir, and Engelmann spruce were the conifers employed. The pines were secured from the Fremont Experiment Station; while the other trees, like the mountain maples, were 
transplanted into appropriate sized containers directly from the forest floor, without disturbing the root system. Care was taken

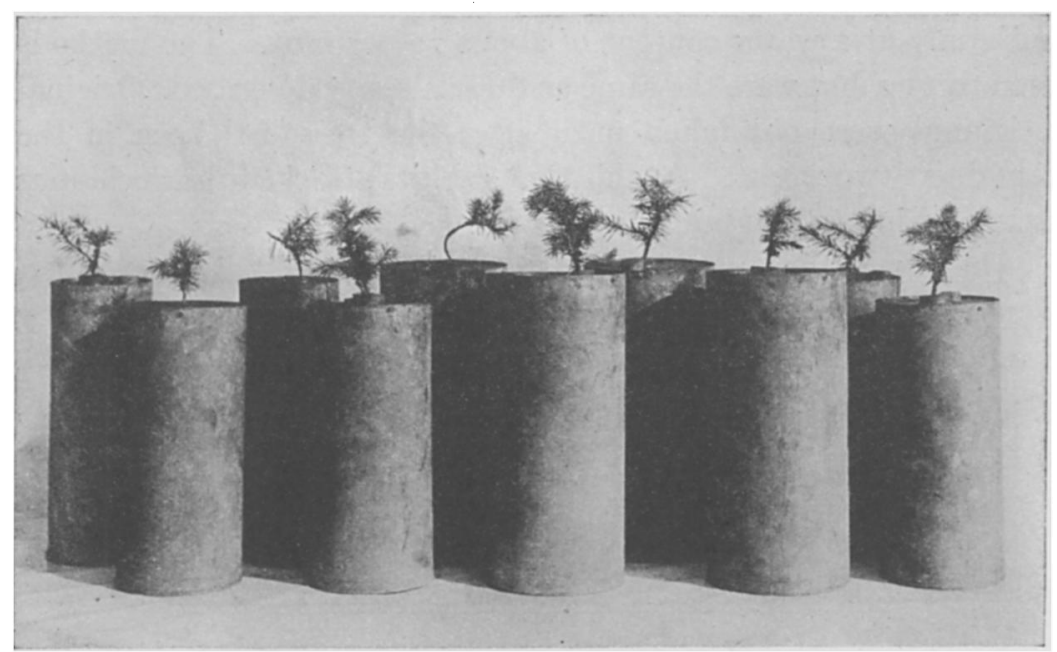

Fig. 17.-Battery of Douglas firs and Engelmann spruces from which summer transpiration losses were obtained.

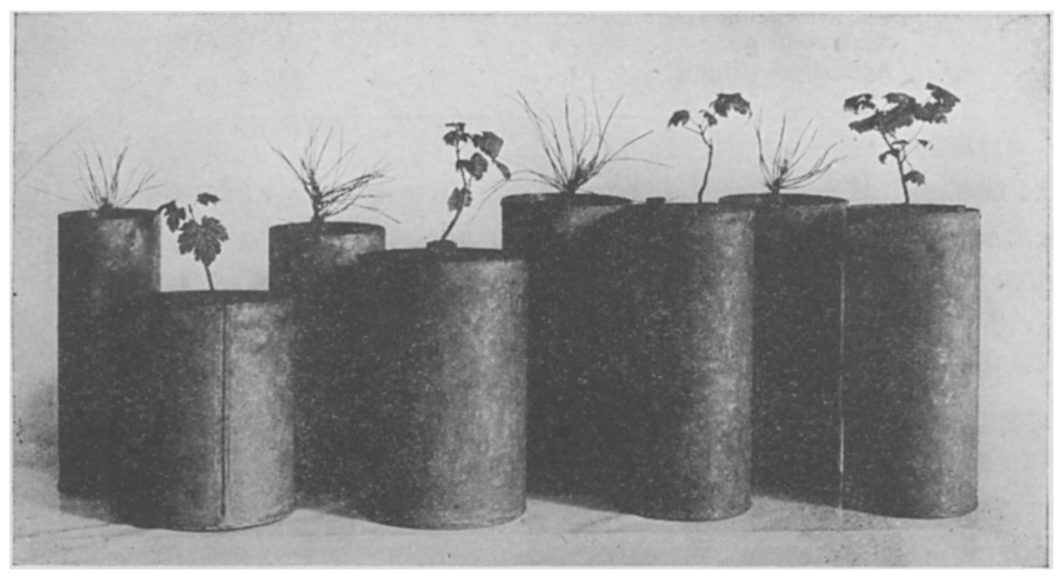

Fig. 18.-Battery of yellow pines and mountain maples used for determining relative summer transpiration.

not to select these species from too dense shade. Some of these trees are shown in figs. $\mathrm{I} 7$ and $\mathrm{I} 8$. 
The extra soil necessary to fill these containers was in all cases a mixture of two parts of garden loam and one part of fine gravel. It had a wilting coefficient of 10.7 per cent, and was kept rather uniformly at a water content of about 20 per cent. The methods used throughout were the same as those already described. Original weighings were not taken until after the trees had been in the containers two weeks. At this time rabbits attacked the deciduous trees and injured all but five of them.

On July 20 the remaining trees in their containers, 19 in number, were weighed to the nearest half gram. As during the preceding interval, they were then placed in a row in the soil and in such a position that all were shaded for a few hours in the afternoon.

TABLE X

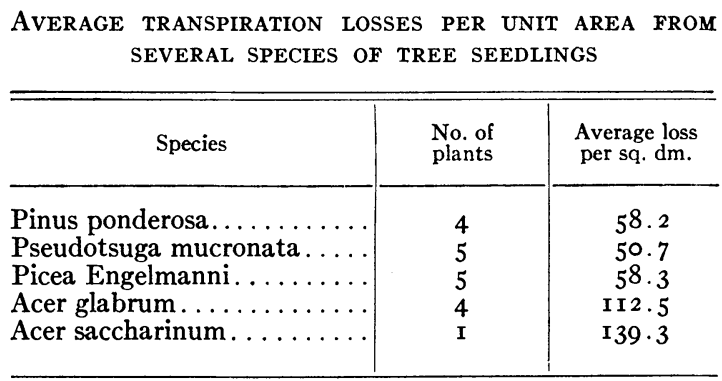

At the end of 26 days, on August 15, they were again weighed, the leaf areas determined, and the losses calculated as in the preceding experiments. These data are shown in table X.

These data show that the losses from the various species of conifers, growing in the open but under conditions where all were shaded for a portion of the day, are very similar, and only about half as great as those of the broad-leaved species. The midsummer average daily loss per square decimeter from the yellow pines and Engelmann spruce at the Alpine Laboratory, when compared with that of the same species during the autumn at Lincoln, was found to be only about half as great at the former station. Because of the limited number of plants used, however, these data should be considered indicative rather than conclusive. 


\section{Conclusions}

A consideration of the foregoing data leads us to some conclusions quite the converse of statements generally current in ecological-physiological literature. Perhaps the most important of these are the facts shown to hold under the conditions of these experiments; first, that broad-leaved trees under late summer conditions have no greater and indeed often a smaller transpiring power, area for area, than conifers; and secondly, that the water losses of coniferous trees during the winter months are relatively no greater with the needles intact than are the losses from deciduous trees after the leaves have fallen.

The fact that all of the plants concerned, including three species and about 30 individuals of broad-leaved trees, and six species represented by about 70 individuals of conifers, gave results which without exception point to these conclusions, leaves little doubt as to the validity of the finds. These results were obtained with all the plants under uniform conditions of soil type and texture, soil temperature, and identical aerial environment. The only variable factor was soil moisture, and here the range was no greater for the one group than for the other. Although the experiments were undertaken near the end of the summer, for a period of a few weeks, after their beginning the deciduous trees were in excellent growing condition, and the comparative losses as here recorded occurred during the earlier part of this period, when the weather was similar to that of midsummer as regards temperature and humidity.

That winter losses from the same leaves that transpired so freely the preceding fall and again in the following spring are so small is certainly testimony of the ecological efficiency of coniferous leaf structure for reducing water losses. Whether this is due entirely to stomatal closure, or, as seems more probable, is connected with chemical changes in cell contents as well, remains to be determined. Such work as that of Mryake (I5) on the food making of coniferous leaves in winter and EHLERS (5) on temperature is rapidly throwing considerable light upon the winter activities of coniferous trees. 
The gradual decline of the transpiring power of broad-leaved trees preceding defoliation and during the formation of the abscisslayer is what might be expected, but is heretofore, we believe, unrecorded. Weather conditions play an important part in hastening or retarding this process, and as a result the dropping off in the transpiration graph. These graphs are surprisingly similar in their general trend to those of conifers where the leaves are intact.

The spring of I9I8 was unfavorable for rapid leafing out or renewed growth of trees. Consequently the increased transpiring power, which is in a direct ratio with the leaf area, occurred very gradually, and here again was not greatly unlike that of the needleleaved trees. Undoubtedly under very favorable weather conditions, as occur during some springs, the transpiring power might easily double or treble day by day for a rather long consecutive period.

\section{Summary}

I. Autumn transpiration losses from conifers are just as great as or even greater than those from broad-leaves.

2. The decrease in water losses from broad-leaved trees resulting from defoliation is gradual, and not greatly unlike the decrease shown in the transpiring power of conifers.

3. Winter transpiration losses from conifers are only $1 / 55^{-}$ $\mathrm{I} / 25^{\mathrm{I}}$ as great as those in autumn.

4. The increased losses of broad-leaved trees in spring occasioned by foliation are in proportion to the leaf areas exposed, and are closely controlled by weather conditions, but in the main are similar to increased losses of conifers.

5. Winter transpiration losses from conifers are scarcely greater than those from defoliated stems of broad-leaved trees.

The writers are indebted to Dr. R. J. Pool for his kindly interest and encouragement, and to Dr. L. J. BRIGGS for wilting coefficient determinations; also to Mr. J. Higgins, of Halsey, Nebraska, and Mr. T. J. LARsen, Priest River, Idaho, for tree 
seedlings from the nurseries, and to Professor T. J. Fitzpatrick for careful reading of the manuscript and proof.

UNIVERSITY OF NeBRASKA

LINCOLN, NEB.

\section{LITERATURE CITED}

I. BEACH, S. A., and Allen, F. W., Jr., Hardiness in the apple as correlated with structure and composition. Iowa Agric. Exp. Sta., Research Bull. 2I, p. I85. I9I5.

2. Bergen, J. Y., Transpiration of sun leaves and shade leaves of Olea europaea and other broad-leaved evergreens. Bот. GAZ. 38:285-296. I9O4.

3. BUrgerstein, A., Über die Transpiration von Taxus-Zweigen bei niederen Temperaturen. Oesterr. Bot. Zeitschr. 25: 1875 .

4. Duhamel, H. L., De l'exploitation des bois. I:337. I764.

5. Ehlers, John H., The temperature of leaves of Pinus in winter. Amer. Jour. Bot. 2:32-70. I9I5.

6. Freeman, Geo. F., Method of determination of transpiration in plants. Bот. GAZ. 46: I18-129. I908.

7. Haberlandt, G., Physiological plant anatomy, p. I38. Trans. from 4th German ed. by Montagu Drummond. London. igi4.

8. Hales, Stephen, Statik der Gewachse, p. 29. I748.

9. Hanson, H. C., Leaf structure as related to environment. Amer. Jour. Bot. 4:533-560. I9I7.

ro. Hartig, T., Über die Bewegung des Saftes in den Holzpflanzen. Bot. Zeit. I9: I7. I86I; and Lehrbuch für Förster I:252. I877.

Ir. ILJIN, V. S., Relation of transpiration to assimilation in steppe plants. Jour. Ecology 4:65-82. I9I6.

I2. Kusano, S., Transpiration of evergreen trees in winter. Jour. Coll. Sci., Imperial Univ. Tokyo r5: part 3. I90I.

13. Livingston, B. E., and Shreve, Edith B., Improvements in the method for determining the transpiring power of plant surfaces by hygrometric paper. Plant World I9:287-309. I9I6.

I4. MacDougall, W. B., The growth of forest tree roots. Amer. Jour. Bot. 3:384-392. I9I6.

I5. MiYaKe, K., On the starch of evergreen leaves and its relation to photosynthesis during the winter. Bот. GAz. 33:32 I-340. I902.

16. Muenscher, W. L. C., A study of the relation of transpiration to the size and number of stomata. Amer. Jour. Bot. 2:487-504. I9I 5 .

17. Stahl, E., Einige Versuche über Transpiration und Assimilation. Bot. Zeit. 52: I I7-I46. I 894 . 
I8. Treviranus, C. L., Physiologie der Gewäsche. r:488. I835.

19. Höhnel, Franz R. von, The physiology of plants, by W. Pfeffer, 2d ed., trans. by A. J. Ewart. I:25I. I900.

20. Warming, Eugene, Oecology of plants. Oxford. Igo9.

2I. Weaver, J. E., and Thiel, A. F., Ecological studies in the tension zone between prairie and woodland. Bot. Survey Neb., conducted by Bot. Seminar, N.S., no. I, Lincoln. I9r 7.

22. Wiesner, J., and PAcher, A., Utber die Transpiration entlauber Zweige und des Stammes der Rosskastanie. Oesterr. Bot. Zeitschr. no. 5. I875; cited by HaberLandt (7, p. I38).

23. Winkler, Albert, Utber den Einfluz der Auszenbedingungen auf die Kälteresistenz ausdauernder Gewächse. Jahrb. Wiss. Bot. (Pringsheim) 52:467-506. I913; abstract in Exper. Sta. Record 30:333. I9I4. 